\title{
PENGARUH KOMBINASI IAA (Indole-3-Acetic Acid) DAN BAP (6-Benzylaminopurine) TERHADAP INISIASI TANAMAN VANILI (Vanilla planifolia Andrews)
}

\author{
Combination Effect of IAA (Indole-3-Acetic Acid) and BAP \\ (6-Benzylaminopurine)on The Initation of Vanili Plant (Vanilla planifolia \\ Andrews)
}

\author{
Apri Salfiani dan Asri Pirade Paserang
}

Jurusan Biologi Fakultas Matematika dan Ilmu Pengetahuan Alam Universitas Tadulako

Keywords:

Vanilla, Combination, IAA, BAP.

Kata kunci :

Vanili, Kombinasi, IAA, BAP.

\begin{abstract}
Provision of Vanilla (Vanilla planifolia Andrews) with traditional cultivation often has problems, including the availability of unhealthy seeds due to disease caused by Fusarium oxysporum. This disease can thwart vanilla plantations up to $85 \%$ because the pathogen can infect all parts of the vanilla plant making it difficult to control efforts. Alternative efforts were made to overcome this problem, namely through the initiation process in tissue culture by combining the hormones IAA (indole-3-acetic acid) and BAP (6-benzylaminopurine). This study aims to determine the effect and the maximum concentration of the combination of IAA and BAP on the initiation of vanilla plants. This study was conducted based on a completely randomized design (CRD) with 5 treatments and 3 repetitions. This treatment consisted of: $A(M S+0.1 \mathrm{ppm}$ IAA $+1 \mathrm{ppm} B A P), B$ $(\mathrm{MS}+0.2 \mathrm{ppm}$ IAA + $1 \mathrm{ppm}$ BAP $), \mathrm{C}(\mathrm{MS}+0.3 \mathrm{ppm}$ IAA + $1 \mathrm{ppm}$ BAP $), \mathrm{D}(\mathrm{MS}+0.4$ ppm IAA + 1 ppm BAP), and $E(M S+0.5$ ppm IAA + 1 ppm BAP). Observations were made after 40 days from the planting process. The results showed that the concentration of the combination of IAA and BAP can affect the growth and organogenesis of the initiation of vanilla plants (Vanilla planifolia Andrews). Treatment $C$ (MS + 0.3 ppm IAA + $1 \mathrm{ppm}$ BAP) was the best concentration from this study, with average values: number of shoots (1), shoot length $(1.73 \mathrm{~cm})$, number of roots (1), and number of leaves (1.33).
\end{abstract}

\begin{abstract}
ABSTRAK
Penyedian Vanili (Vanilla planifolia Andrews) dengan pembudidayaan tradisional sering mempunyai kendala, diantaranya ketersediaan bibit yang kurang sehat akibat serangan penyakit yang disebabkan oleh Fusarium oxysporum. Penyakit ini dapat menggagalkan pertanaman Vanili sampai $85 \%$ karena patogen tersebut dapat menginfeksi seluruh bagian tanaman Vanili sehingga menyulitkan usaha pengendaliannya. Upaya alternatif dilakukan untuk mengatasi masalah tersebut, yaitu melalui proses inisiasi dalam kultur jaringan dengan mengkombinasikan hormon IAA (indole-3- acetic acid) dan BAP (6benzylaminopurine). Penelitian ini bertujuan untuk mengetahui pengaruh serta konsentrasi yang paling maksimal dari kombinasi IAA dan BAP terhadap inisiasi tanaman Vanili. Penelitian ini dilakukan berdasarkan Rancangan Acak Lengkap (RAL) dengan 5 perlakuan dan pengulangan sebanyak 3 kali. Perlakuan ini terdiri dari: $A(M S+$ $0,1 \mathrm{ppm}$ IAA + 1 ppm BAP), B (MS + 0,2 ppm IAA + 1 ppm BAP), C (MS +

0,3 ppm IAA + 1 ppm BAP), D (MS + 0,4 ppm IAA + 1 ppm BAP), dan E (MS + 0,5 ppm IAA + 1 ppm BAP). Pengamatan dilakukan setelah 40 hari dari proses penanaman. Hasil Penelitian didapatkan Konsentrasi kombinasi IAA dan BAP dapat mempengaruhi pertumbuhan serta organogenesis pada inisiasi tanaman Vanili (Vanilla planifolia Andrews). Perlakuan $\mathrm{C}(\mathrm{MS}+0,3 \mathrm{ppm} \mathrm{IAA}+1 \mathrm{ppm}$ BAP) merupakan konsentrasi terbaik dari penelitian ini, dengan nilai rata-rata: jumlah tunas (1), panjang tunas $(1,73$ $\mathrm{cm})$, jumlah akar (1), serta jumlah daun $(1,33)$.
\end{abstract}




\section{PENDAHULUAN}

Vanili (Vanilla planifolia Andrews) merupakan salah satu tanaman bernilai ekonomi tinggi. Namun, penyediaan Vanili terutama dengan pembudidayaan tradisional sering mempunyai kendala, seperti bibit dan tanaman induk yang kurang sehat akibat serangan penyakit yang disebabkan oleh Fusarium oxysporum. Penyakit ini dapat menggagalkan pertanaman Vanili sampai $85 \%$ karena patogen tersebut dapat menginfeksi seluruh bagian tanaman Vanili sehingga menyulitkan usaha pengendaliannya. Upaya yang harus dilakukan untuk mengatasi masalah tersebut adalah perlunya memperbaiki teknik budidaya agar didapatkan tanaman Vanili yang berkualitas baik. Salah satu alternatif yang dapat dilakukan adalah melalui proses inisiasi dalam kultur jaringan. Inisiasi adalah pengambilan eksplan dari bagian tanaman yang akan dikulturkan (Erawati dkk 2021; Sudrajad dkk, 2016; Lestari dkk, 2006).

Pada kultur jaringan, penggunaan zat pengatur tumbuh (ZPT) sangat penting dalam pertumbuhan eksplan. Ada dua golongan ZPT tanaman yang sering digunakan dalam kultur jaringan, yaitu sitokinin dan auksin (Wahyuni dkk, 2019). Penambahan auksin atau sitokinin ke dalam media kultur dapat menjadi faktor pemicu dalam proses tumbuh dan perkembangan jaringan. Selain itu, kombinasi antara sitokinin dengan auksin juga dapat memacu morfogenesis dalam pembentukan tunas (Lestari, 2011).

Penggunaan jenis auksin dan sitokinin dalam kultur tanaman Vanili telah dilaporkan, diantaranya menggunakan IAA (indole-3acetic acid) dan BAP (6- benzylaminopurine). Pada media $1 / 2$ MS (Murashige and Skoog) yang dikombinasikan dengan $0,5 \mathrm{mg} \mathrm{L}-1$ IAA, menghasilkan jumlah akar 4,00 per plantlet dengan panjang rata-rata $6,1 \mathrm{~cm}$. Sedangkan untuk media MS dengan penambahan $1 \mathrm{mg} \mathrm{L-1} \mathrm{BAP,} \mathrm{dapat} \mathrm{diperoleh}$ perkembangan tunas yang maksimal (Ayele et al., 2017; Dolce et al., 2019). Akan tetapi, kombinasi antara IAA dan BAP terhadap tanaman Vanili masih perlu dilakukan kajian lebih lanjut. Sementara itu, penggunaan kombinasi IAA dan BAP yang telah dilakukan untuk kultur tanaman diantaranya pada jenis anggrek Dendrobium (Dilshad et al., 2007; Khatun et al., 2007) dan Smithsonia maculata (Dalz.) Saldanha (Decruse and Gangaprasad, 2018), dimana mampu mendorong proses organogenesis dengan baik yang ditandai dengan pembentukan akar, tunas, serta daun. Hasil tersebut menunjukkan bahwa kombinasi IAA dan BAP sangat potensial digunakan dalam perbanyakan tanaman. Untuk itu, penelitian ini dilakukan guna mengetahui pengaruh kombinasi antara IAA dan BAP terhadap 
inisiasi tanaman Vanili (V. planifolia Andrews).

Penelitian ini bertujuan untuk mengetahui pengaruh serta konsentrasi yang paling maksimal dari kombinasi IAA (indole-3acetic acid) dan BAP (6- benzylaminopurine) terhadap inisiasi tanaman Vanili (V. planifolia Andrews).

\section{BAHAN DAN METODE}

\section{Bahan}

Penelitian telah dilaksanakan pada bulan November 2020 sampai dengan Maret 2021, bertempat di Laboratorium Bioteknologi dan Genetika Jurusan Biologi Fakultas Matematika dan IImu Pengetahuan Alam Universitas Tadulako. Untuk Eksplan tanaman vanili ( $V$. planifolia Andrews), diambil dari perkebunan masyarakat Desa Lembantongoa, Kecamatan Palolo, Kabupaten Sigi, Sulawesi Tengah.

Alat yang digunakan pada penelitian ini adalah gunting stek untuk mengambil Eksplan. Sedangkan alat laboratorium yaitu botol kultur, rak kultur, autoklaf, oven, laminar air flow (LAF), peralatan diseksi, cawan petri, $\mathrm{pH}$ meter, timbangan analitik, hand sprayer, magnetic strirer, hot plate, erlenmeyer, gelas ukur, pipet tetes, lemari pendingin, air conditioner (AC), lampu LED, time limiter, sendok, corong, mikroskop, cawan aluminium, bunsen dan korek api. Selain itu digunakan alat tulis dan kamera digital untuk mencatat informasi penting serta mendokumentasikan kegiatan selama penelitian.

Bahan yang digunakan adalah Eksplan tanaman Vanili (V. planifolia Andrews), medium MS, plastik klip, agar swallow, sukrosa, BAP, IAA, buffer 4 dan 7, HCL 1

$\mathrm{N}, \mathrm{KOH} 1 \mathrm{~N}$, alkohol $96 \%$ dan $70 \%$, akuades, deterjen Tween 80, fungisida Masalgin, bakterisida Streptomycin, Bayclin, spiritus, sabun cuci Sunlight, spons, tisu, kertas saring, plastik tahan panas, karet gelang, sarung tangan, label, plastik wrapping, serta kertas milimeter blok.

Alat yang digunakan terlebih dahulu dicuci kemudian disterilisasi. Hal pertama yang dilakukan adalah menimbang bahan yang digunakan yaitu media MS instan, sukrosa, agar, zat pengatur tumbuh berupa IAA sebanyak 0,1 ppm, 0,2 ppm, 0,3 ppm, 0,4 ppm, 0,5 ppm dan BAP sebanyak $1 \mathrm{ppm}$.

Eksplan yang akan digunakan disterilisasi dengan larutan deterjen Tween 80/100 ml akuades selama 3 menit. Dibilas dengan akuades. Direndam fungisida Masalgin $2 \mathrm{~g} / \mathrm{L}$ akuades steril selama $1 \mathrm{jam}$. Dibilas dan di rendam dengan larutan bakterisida Streptomycin 0,8 g/L akuades selama $1 \mathrm{jam}$. Setelah itu di bilas lalu direndam lagi dengan larutan Bayclin $40 \%$ selama 40 menit kemudian dibilas dan direndam kembali dengan larutan Bayclin 35\% selama 35 menit. Bilas kembali dan terakhir di rendam pada alkohol $70 \%$ selama 1 menit kemudian di bilas. Kemudian dilanjutkan dengan proses 
penanaman dan di inokulasi pada media MS yang telah di tambahkan hormon IAA dan BAP dengan 5 konsentrasi yang berbeda. HASIL DAN PEMBAHASAN

\section{Jumlah Tunas}

Berdasarkan hasil analisis varians jumlah tunas, perlakuan dari kombinasi hormon IAA dan BAP tidak berpengaruh nyata terhadap
Semua proses kerja dilakukan di dalam LAF dan ruangan steril. Pengamatan dilakukan setelah 40 hari dari proses penanaman. jumlah tunas eksplan tanaman Vanili ( $V$. planifolia Andrews), sehingga tidak dilakukan uji lanjut Duncan. Adapun rataan jumlah tunas disajikan dalam diagram berikut ini:

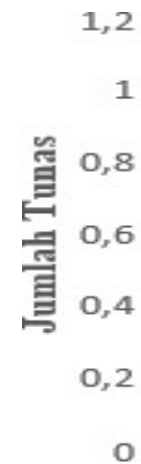

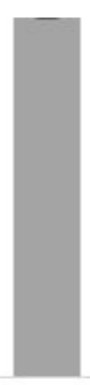

A

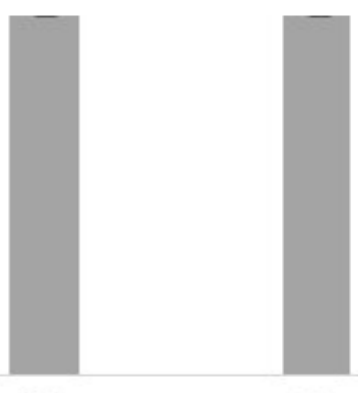

C

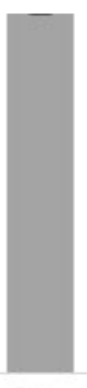

$\mathrm{D}$

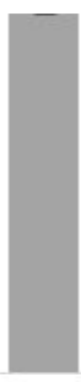

$\mathrm{E}$

Perlakuan

Gambar 1. Diagram rata-rata jumlah tunas eksplan Vanili (V. planifolia Andrews)

Eksplan yang ditumbuhkan pada semua perlakuan (A sampai dengan E) dari kombinasi hormon IAA dan BAP, menunjukkan rata-rata jumlah tunas yang sama yaitu 1.

\section{Panjang Tunas}

Analisis varians pada panjang tunas menunjukkan hasil yang tidak berpengaruh nyata $(P>0,05)$ sehingga tidak dilakukan uji lanjut Duncan. Rata-rata panjang tunas disajikan dalam diagram berikut ini (Gambar 2).

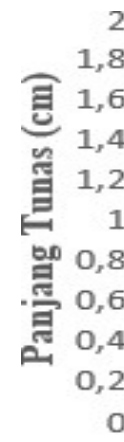

0
B

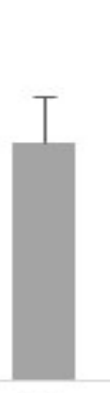

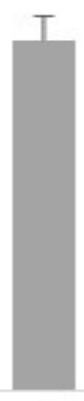

C

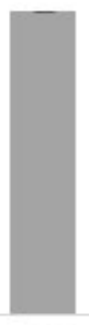

D

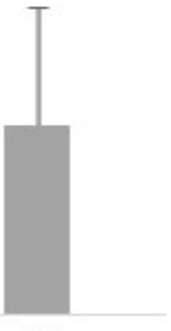

$\mathrm{E}$

Perlakuan

Gambar 2. Diagram rata-rata panjang tunas eksplan Vanili (V. planifolia Andrews) ISSN-P : 1978-6417; ISSN-E : 2580-5991 
Eksplan yang ditumbuhkan pada perlakuan C menunjukkan nilai rata-rata tertinggi yaitu $1,73 \mathrm{~cm}$, kemudian di ikuti perlakuan $\mathrm{D}$ dengan nilai $1,5 \mathrm{~cm}$, perlakuan $B 1,17 \mathrm{~cm}$, Jumlah Akar

Hasil perhitungan analisis varians dari perlakuan kombinasi hormon IAA dan BAP menunjukkan pengaruh nyata $(P<0.05)$ terhadap jumlah akar eksplan tanaman Vanili (V. planifolia Andrews), sehingga dilakukan perlakuan A $1,07 \mathrm{~cm}$, dan nilai rata-rata terkecil diperoleh pada perlakuan E sebesar $0,93 \mathrm{~cm}$.

uji lanjut Duncan untuk mengetahui perlakuan mana yang berpengaruh terhadap jumlah akar pada eksplan tanaman Vanili (lampiran 3). Nilai rata-rata hasil analisis disajikan pada diagram berikut.

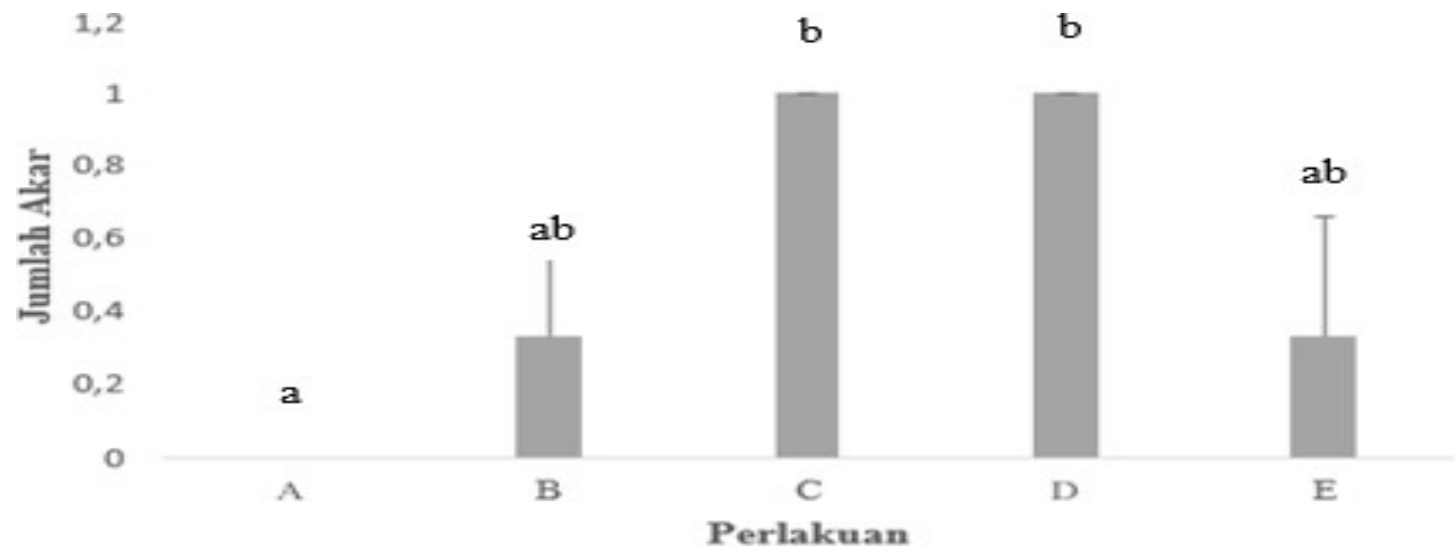

Gambar 3. Diagram rata-rata jumlah akar eksplan Vanili (V. planifolia Andrews)

Menunjukkan nilai tertinggi rata-rata jumlah akar pada eksplan tanaman Vanili ( $V$. planifolia Andrews) diperoleh pada perlakuan C dan $D$ sebesar 1. Selanjutnya perlakuan B, juga $E$ dengan nilai 0,33 serta nilai rata-rata terkecil, didapatkan pada perlakuan $\mathrm{A}$ yaitu 0 .

\section{Panjang akar}

Berdasarkan hasil analisis varians panjang akar, perlakuan dari kombinasi hormon IAA dan BAP ttidak berpengaruh nyata $(P>0,05)$ sehingga tidak dilakukan uji lanjut Duncan. Berikut ini merupakan diagram yang ISSN-P : 1978-6417; ISSN-E : 2580-5991 menampilkan nilai rata-rata panjang akar dari eksplan tanaman Vanili (V. planifolia Andrews) terhadap berbagai perlakuan kombinasi hormon IAA dan BAP.

Diagram dari gambar 4. menunjukkan nilai rata-rata tertinggi diperoleh pada perlakuan D $(2,03 \mathrm{~cm})$, selanjutnya perlakuan C (1,3 $\mathrm{cm}$ ), dan perlakuan $\mathrm{E}$ dengan nilai $0,83 \mathrm{~cm}$, serta perlakuan $B(0,1 \mathrm{~cm})$. Sedangkan nilai rata-rata panjang akar eksplan tanaman Vanili yang terkecil didapatkan dari perlakuan $A$ yaitu sebesar $0 \mathrm{~cm}$. 


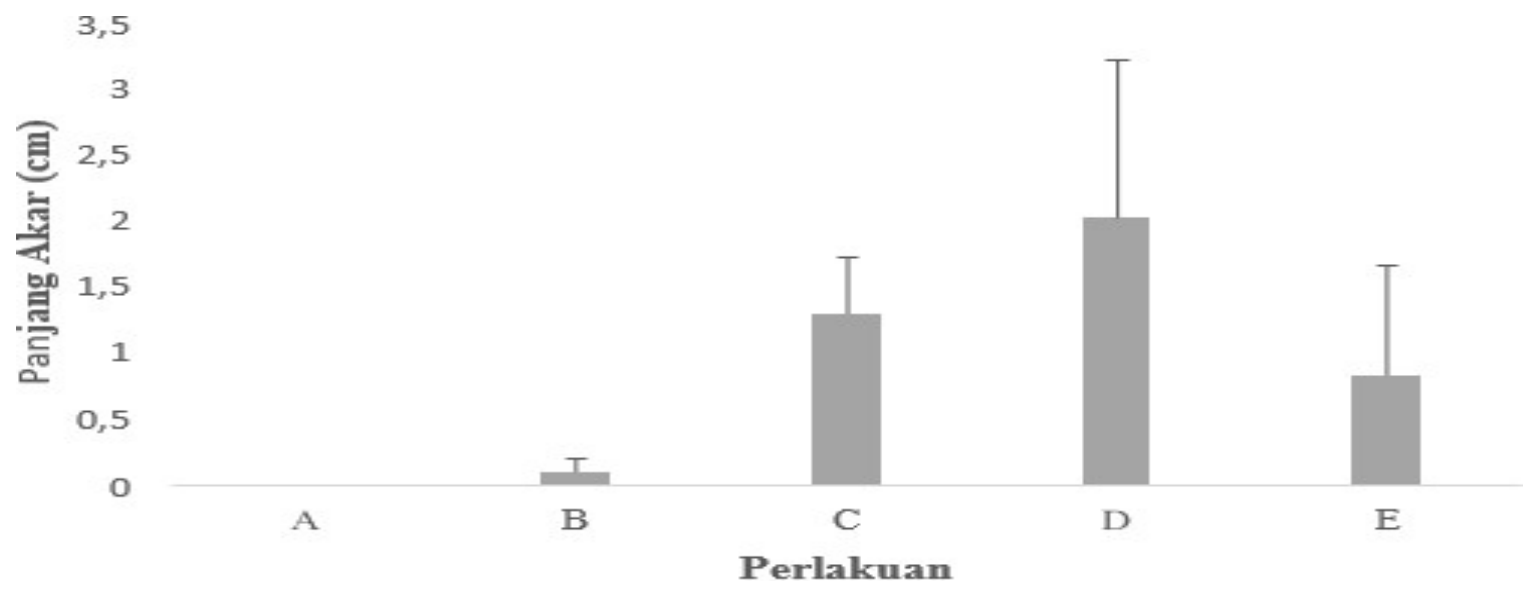

Gambar 4. Diagram rata-rata panjang akar eksplan Vanili (V. planifolia Andrews)

\section{Jumlah Daun}

Berdasarkan perlakuan berbagai kombinasi hormon IAA dan BAP tidak berpengaruh nyata terhadap jumlah daun eksplan tanaman Vanili (V. planifolia Andrews).Hal ini karena $(P)>0,05$ sehingga tidak dilakukan uji lanjut Duncan. Adapun mengenai ratarata jumlah daun disajikan dalam diagram berikut ini:

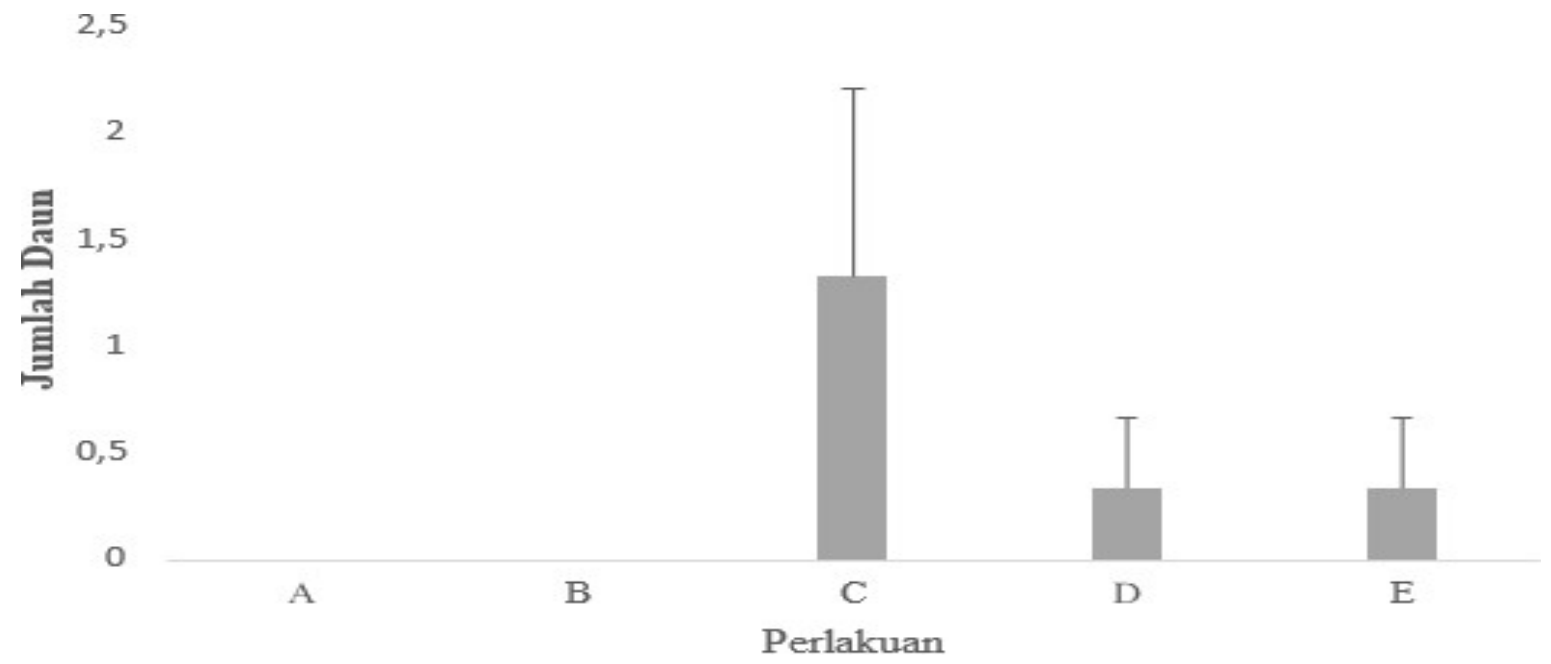

Gambar 5. Diagram rata-rata jumlah daun eksplan Vanili (V. planifolia Andrews)

Dari hasil diagram dalam gambar 5 , nilai rataan jumlah daun yang didapatkan pada masing-masing perlakuan adalah 0 sampai dengan 1,33 . Nilai tertinggi diperoleh pada perlakuan $C(1,33)$, selanjutnya perlakuan D dan E dimana kedua perlakuan tersebut 
mempunyai nilai yang sama sebesar 0,33 serta nilai rata-rata terkecil dapat dilihat pada perlakuan A juga $B$ yaitu 0 .

Hasil penelitian menunjukkan bahwa konsentrasi kombinasi dari IAA (indole-3acetic acid) dengan BAP (6Benzylaminopurine) mampu menginduksi tunas, akar, dan daun pada eksplan tanaman Vanili (V. planifolia Andrews) pada beberapa perlakuan, serta dapat memacu organogenesis. Menurut Marzuki dkk (2016), Respon organogenesis tanaman secara in vitro terjadi dengan dua cara yang berbeda yaitu secara langsung dan tidak langsung. Organogenesis secara langsung merupakan proses tanpa didahului dengan terbentuknya kalus. Pada penelitian ini organogenesis eksplan tanaman Vanili terjadi secara langsung. Perlakuan yang tidak dapat menginduksi dan mendorong organogenesis pembentukan akar dan daun yaitu pada media dengan menghasilkan organogenesis yang optimal.

Penambahan zat pengatur tumbuh auksin pada eksplan dengan konsentrasi rendah dan sitokinin yang tinggi, menghasilkan pembentukan tunas yang baik dibandingkan dengan media tanam dengan ZPT yang memiliki konsentrasi auksin tinggi dan sitokinin yang rendah. Hal tersebut seperti hasil penelitian terhadap induksi tunas mikro dari eksplan bonggol pisang Kepok konsentrasi $\mathrm{MS}+0,1 \mathrm{ppm} \mathrm{IAA}+1 \mathrm{ppm}$ BAP (A). Sedangkan perlakuan $B(M S+$ 0,2 ppm IAA + 1 ppm BAP) tidak dapat mempengaruhi pembentukan daun. Untuk perlakuan terbaik dari penelitian ini diperoleh pada media kombinasi $\mathrm{MS}+0,3$ ppm IAA + 1 ppm BAP (C) karena mampu menginduksi dan memacu organogenesis tunas, akar, daun, selain itu media tersebut memperoleh nilai rata-rata tertinggi dari semua perlakuan. Nilai rata-rata yang diperoleh dari perlakuan $\mathrm{C}$ antara lain: jumlah tunas (1), panjang tunas $(1,73 \mathrm{~cm})$, jumlah akar (1), serta jumlah daun $(1,33)$. Sedangkan nilai rataan tertinggi dari panjang akar ditunjukkan pada perlakuan $\mathrm{D}$ (MS + 0,4 ppm IAA + 1 ppm BAP) dengan nilai $2,03 \mathrm{~cm}$. Untuk perlakuan yang tidak optimal diperoleh perlakuan $A$. Menurut mahadi (2016), keseimbangan antara hormon endogen dan ZPT pada media

akan

(Musa paradisiaca L), dimana kombinasi perlakuan $4 \mathrm{mg} / \mathrm{l} \mathrm{IAA}+6 \mathrm{mg} / \mathrm{l}$ BAP menghasilkan pertumbuhan tunas terbaik (Sadat dkk, 2018). Pada penelitian ini, pertumbuhan tunas dari semua perlakuan meliputi jumlah tunas di dapatkan nilai ratarata 1 , dan panjang tunas 0,93 sampai dengan $1,73 \mathrm{~cm}$ tetapi nilai keduanya tidak berbeda nyata, sama halnya seperti panjang akar serta jumlah daun. Hasil berbeda nyata 
hanya ditunjukkan oleh parameter jumlah akar.

Keberhasilan kultur jaringan tidak hanya dipengaruhi zat pengatur tumbuh saja, namun jenis maupun ukuran eksplan atau bahan tanam juga merupakan salah satu faktor yang menentukan. Setiap jenis tanaman maupun organ memiliki ukuran optimum untuk dikulturkan, eksplan yang terlampau kecil akan kurang daya tahannya jika dikulturkan, sementara bila terlalu besar akan sulit mendapatkan eksplan yang steril. Tanaman herba pada umumnya lebih mudah diregenerasikan dibandingkan tanaman berkayu. Namun demikian pada tanaman berkayu tertentu seperti jati, cendana dan sukun tidak sulit diperbanyak secara in vitro, hal ini menunjukkan bahwa faktor genetik juga menentukan kemampuan regenerasi tunas (Marzukidkk, 2016).

\section{PEMBAHASAN}

Secara umum mekanisme mikroorganisme yang digunakan sebagai pupuk hayati dalam meningkatkan pertumbuhan adalah melalui fiksasi nitrogen, meningkatkan kelarutan mineral dan fosfat, memproduksi enzim yang mendegradasi makromolekul, menghasilkan fitohormon dan menghasilkan senyawa volatil yang mestimulasi pertumbuhan (Borris, 2011). Adapun peran dari masing-masing mikroorganisme dalam pupuk hayati $\mathrm{X}$ adalah sebagai berikut: a. Azotobacter sp mampu mengikat nitrogen yang ada di udara sehingga berkontribusi terhadap ketersediaan nitrogen di dalam tanah setelah terjadi kematian sel bakteri tersebut. Selain itu juga mampu menghasilkan auksin, sitiokinin dan giberelin (Jnawali et al., 2015), b. Azospirillum sp mampu untuk mengikat nitrogen di udara dan menghasilkan fitohormon terutama auksin (Fukami et al., 2018), c. Trichoderma sp mampu mempercepat proses dekomposisi karena mampu mendegradasi dinding sel (Waghunde et al., 2016), d. Lactobacillus sp dapat menghasilkan auksin (AfanadorBarajas et al., 2021). Adapun peran mikroorganisme dari pupuk hayati $Y$ adalah: a. Stenotrophomonas sp mampu melarutkan fosfat inorganik, menghasilkan auksin dan siderofor. Siderofor berperan untuk membantu penyerapan $\mathrm{Fe}$ (Patel and Saraf, 2017),

b. Paenibacillus polymyxa mampu mengikat nitrogen di udara dan menghasilkan auksin (Jeong et al., 2019).

Parameter pertumbuhan yang representatif adalah berat kering tanaman karena berat kering tanaman merupakan gabungan dari semua peristiwa fisiologis tanaman (Sitompul dan Guritno, 1995). Berdasarkan berat kering tanaman yang diukur, pupuk hayati $Y$ lebih meningkatkan pertumbuhan dibandingkan dengan pupuk hayati $X$. Pemberian pupuk hayati $X$ cenderung menurunkan berat kering tanaman. 
Aplikasi pupuk hayati tidak selalu meningkatkan pertumbuhan tanaman (Afanador-Barajas et al., 2021). Beberapa faktor yang harus diperhatikan dalam penggunaan pupuk hayati adalah komposisi dari mikroorganisme yang digunakan (Laditi et al., 2011) jenis tanaman yang dipilih, tingkat dan jenis pemupukan pada media tanam (Vandenberghe et al., 2017). Aplikasi pupuk hayati tanpa pemberian unsur hara justru akan menurunkan pertumbuhan tanaman karena mikroorganisme dalam pupuk hayati berkompetisi dengan tanaman terhadap unsur hara. Tidak berfungsinya mikroorganisme pada pupuk hayati dalam meningkatkan pertumbuhan tanaman juga

\section{DAFTAR PUSTAKA}

Afanador-Barajas, L. N., Navarro-Noya, Y. E., Luna-Guido, M. L., and Dendooven, L. (2021). Impact of a bacterial consortium on the soil bacterial community structure and maize (Zea mays L.) cultivation. Scientific Reports, 11: 13092.

Bhattacharjee, R. and Dey U. (2014). Biofertilizer, a way towards organic agriculture: a review. African Journal of Microbiology Research, 8(24): 2332-2342.

Borriss, R. (2011). Use of plant-associated Bacillus strains as biofertilizers and biocontrol agents in agriculture. In $\mathrm{D}$. K. Maheswari (ed.), Bacteria in agrotebiology: Plant growth responses. (pp. 41-75) Berlin: Springer-Verlag. bisa disebabkan oleh sulitnya mikroorganisme melakukan kontak dengan akar yang tumbuh ketika pupuk hayati tersebut diberikan melalui permukaan tanah (Afanador-Barajas et al., 2021). Media pembawa yang sesuai juga akan mempengaruhi kualitas dari pupuk hayati yang digunakan (Bhattacharjee and Dey, 2014).

Penggunaan pupuk hayati dapat berperan atau tidak berperan dalam meningkatkan pertumbuhan tanaman jagung. Beberapa hal yang harus diperhatikan dalam aplikasi pupuk hayati seperti komposisi mikroorganisme dalam pupuk hayati, jenis tanaman, tingkat pemupukan, dan cara pemberian pupuk ke tanaman.

Edi, S. (2019). Analisis faktor-faktor yang mempengaruhi perilaku konsumen terhadap permintaan jagung pada tingkat rumah tangga di Kecamatan Pasarwajo Kabupaten Buton. Intelektiva: Jurnal Ekonomi, Sosial dan Humanoria, 1(5): 90-100.

Fukami, J., Cerezini, P., and Hungria, M. (2018). Azospirillum: benefits that go far beyond biological nitrogen fixation. AMB Express, 8(73):1-12.

Jeong, H., Choi, S. K., Ryu, C. M., and Park, S. W. (2019). Chronicle of a soil bacterium: Paenibacillus polymmyca E681 as a tiny guardian of plant and human health. Frontier in Microbiology, 10: 1-16.

Jnawali, A. D., Ojha, R. B., and Marahatta, S. (2015). Role of Azotobacter in soil 
fertility and sustainability-a review. Advances in Plants and Agricultural Research, 2(6): 250-253.

Laditi, M., Jemo, M., Nwoke, O. C., and Abaidoo, R. C. (2012). Evaluation of microbial inoculants as biofertilizer for the improvement of growth and yield of soybean and maize crops in savanna soils. African Journal of Agricultural Research, 7(3): 405-413.

Maulana, Z., Zaitun and Jumini. (2015). The effect of bio liquid fertilized application on the growth of two varieties of maize (Zea mays L.). Proceedings of The 5th Annual International Conference Syiah Kuala University (AIC Unsyiah) Sepetember 9-11. Banda Aceh. Indonesia.

Nugraha, R., Ardyati, T., dan Suharjono. (2014). Explorasi bakteri selulolitik yang berpotensi sebagai agen biofertilizer dari tanaman perkebunan apel Kota Batu, Jawa Timur. Jurnal Biotropika, 2(3): 159-163.

Patel, T., and Saraf, M. (2017). Exploration of novel plant growth promoting bacteria Stenotrophomonas maltophilia MTP42 isolated from the rhizospheric soil of Coleus forskohlii. International Journal of Current Microbiology and Applied Sciences, 6(11):1-12.

Santos, V. B., Araujo, A. S. F., Leite, L. F. C., Nunes, L. A. P. L., and Melo, W. J. (2012). Soil microbial biomass and organic matter fraction during transition from conventional to organic farming systems. Geoderma, 227231.

Savci, S. (2012). An agricultural pollutant: Chemical fertilizer. International Journal of Environmental Science and Development, 3(1)): 77-80.

Simanjuntak, A., Lahay, R. R., dan Purba, E. (2013). Respon pertumbuhan dan produksi bawang merah (Allium ascalonicum L) terhadap pemberian pupuk NPK dan kompos kulit buah kopi. Jurnal Online Agroekoteknologi, 1(3): 362-373.

Sitompul, S. M. dan Guritno, B. (1995). Analisis Pertumbuhan Tanaman. Yogyakarta: Gadjah Mada University Press.

Sudiarti (2017). Efektivitas biofertilizer pada pertumbuhan tanaman kedelai edamame (Glycin max). Jurnal SainHelath, 1(2): 46-55.

Vandenberghe, L. P. S., Garcia, L. M. B., Rodrigues, C., Camara, M. C., Pereira, G. V. M., de Oliveira, J., and Soccol, C. R. (2017). Potential application of plant probiotic microorganisms in agricultural and forestry. AIMS Microbiology, 3(3): 629-648.

Waghunde, R. R., Shelake, R. M., Sabalpara, A. N. (2016). Trichoderma; a significant fungus for agriculture and environment. African Journal of Agricultural Research, 11(22): 19521956. 